\title{
Nitrofurantoin Resistance Among Common Urinary Isolates in Uncomplicated Urinary Tract Infection
}

\author{
Purba Mukherjee ${ }^{1}$,Supriya Bal ${ }^{2}$, and P.S.Satpathi ${ }^{2}$ \\ ${ }^{1,2}$ Demonstrator, Department Of Microbiology, Midnapore Medical College And Hospital, Paschim Midnapur, \\ West Bengal \\ ${ }^{3}$ Associate Professor, Department Of Microbiology, Midnapore Medical College And Hospital, Paschim \\ Midnapur, West Bengal,
}

\begin{abstract}
Despite being a common health problem, community acquired uncomplicated Urinary Tract Infection (UTI) is a bit under-rated because of its lower mortality rate, relative ease of diagnosis and easily available oral remedy for it. But ever increasing antibiotic -resistance of the uropathogens has forced us to have another look into this matter. This study is an effort to see whether the less commonly prescribed oral antibiotic like Nitrofurantoin can be a better option for treatment before switching over to the final option of intravenous antibiotic therapy.Mid-stream urine samples were collected from 642 symptomatic UTI patients, out of which, 111 were culture positive. The predominant organism was Escherichia coli, CONS, S. aureus, Klebsiella species. Very high level of resistance was observed against fluoroquinolones, ampicillin, amoxycillin -clavulanic acid, cephalosporins. But, Nitrofuranrtoin resistance was relatively less-21\%. The other antibiotics which showed equal or higher level of susceptibility than Nitrofurantion were all injectable preparationsImipenem, Cefoperazone-sulbactam, Amikacin and Gentamicin. So, in the current scenario, use of Nitrofutantion to treat uncomplicated community acquired UTI should be considered in our state.
\end{abstract}

Keywords: Community acquired UTI, Nitrofurantion resistance, Urinary tract infection, UTI

\section{Introduction}

Community acquired urinary tract infection (UTI), although a common infection, enjoys a lesser importance due to the following perceptions- lower mortality rate of uncomplicated UTI, relative ease of diagnosis by simple mid- stream urine culture and ease of treatment by simple short course chemotherapy.

Nevertheless, data of increased prevalence, cost, morbidity, antibiotic resistance, recurrence and relapse suggest that clinician should have another look to community acquired uncomplicated UTI. ${ }^{1}$

Typically there are fewer and fewer oral antibiotic choices, and the question is: What compounds might we have at hand to use, or do we need to resort to intravenous antibiotic therapy? This is an increasingly frequent problem. David Livermore has published a nice series on Klebsiella pneumoniae carbapenemase (KPC) organisms and found that less than a quarter of them are still susceptible to either ciprofloxacin, chloramphenicol, or nitrofurantoin. ${ }^{2}$

\section{Materials And Methods}

Mid -stream urine specimens were collected from patients presenting with clinical symptoms of urinary tract infections. Urine specimens were inoculated in MacConkey's agar and CLED agar following standard protocol. The isolates were identified by the sets of standard biochemical reactions i.e. Indole production, MR reaction, VP test, Citrate utilisation, Urease production, sugar fermentation reactions and other phenotypic methods. Antibiotic sensitivity was done by Kirby- Bauer method on Müller Hinton agar plate. The results were analysed and interpreted as standard CLSI guidelines.

\section{Result And Analysis}

Altogether 642 patients with suspected urinary tract infection were included in this study. Mid-stream urine specimens were collected from them using standard collection technique. 111 were culture positive. The microbial profile of the culture positive urine was predominated by Escherichia coli, followed by Coagulase negative Staphylococcus Species (CONS), Staphylococcus aureus, Enterococcus faecalis, and Klebsiella species. Several other species were also involved like Proteus vulgaris and Proteus mirabilis, Citrobactor species, Pseudomonas species, and Serratia sp.(in one case).

Antibiogram of the isolates showed varied degree of resistance. Nitrofurantion (NFT) resistance was seen in 24 isolates(21.62\%). 8 E. coli, 5 Klebsiella sp.,5 Enterococcus sp., 2 CONS, and one each for S. aureus, Proteus sp., Citrobactor sp., and Pseudomonas Sp. were NFT resistant. Majority of the isolates were mostly sensitive to nitrofurantoin, whereas, resistant to most of the commonly employed antibiotics for UTI. 


\section{Figures and tables}

Table: 1. Bacteriological profile of UTI $(\mathrm{n}=111)$

\begin{tabular}{|l|l|l|}
\hline Organism & Number & Percentage \\
\hline E. coli & 42 & 37.84 \\
\hline CONS. & 16 & 14.41 \\
S. aureus & 14 & 12.61 \\
\hline Klebsiella species & 13 & 11.71 \\
\hline Enterococcus Sp. & 13 & 11.71 \\
\hline Pseudomonas sp. & 5 & 4.50 \\
Proteus sp & 2 & 1.80 \\
\hline Citrobactor sp. & 5 & 4.50 \\
\hline Serratia sp. & 1 & 0.90 \\
\hline
\end{tabular}

Table 2: antibiotic sensitivity pattern of the isolates against commonly used antibiotics

\begin{tabular}{|c|c|c|c|c|c|c|c|c|}
\hline $\begin{array}{l}\text { Anti- } \\
\text { biotics }\end{array}$ & $\begin{array}{l}\text { E. coli } \\
42\end{array}$ & $\begin{array}{l}\text { CONS } \\
16\end{array}$ & $\begin{array}{l}\text { S. aureus } \\
14\end{array}$ & $\begin{array}{l}\text { Klebsiella sp. } \\
13\end{array}$ & $\begin{array}{l}\text { Entero } \\
\text { Coccus Sp. } \\
13\end{array}$ & $\begin{array}{l}\text { Proteus sp. } \\
2\end{array}$ & $\begin{array}{l}\text { Citro } \\
\text { bactor } \\
\text { sp. } \\
5 \\
\end{array}$ & $\begin{array}{l}\text { Pseudo } \\
\text { monas } \\
\text { sp. } \\
5 \\
\end{array}$ \\
\hline $\begin{array}{l}\text { Amc } \\
\mathrm{S} \\
\mathrm{R}\end{array}$ & $\begin{array}{l}4 \\
38 \\
\end{array}$ & $\begin{array}{l}12 \\
4 \\
\end{array}$ & $\begin{array}{l}8 \\
6 \\
\end{array}$ & $\begin{array}{l}2 \\
11 \\
\end{array}$ & $\begin{array}{l}4 \\
9 \\
\end{array}$ & $\begin{array}{l}1 \\
1\end{array}$ & $\begin{array}{l}3 \\
2 \\
\end{array}$ & $\begin{array}{l}1 \\
4 \\
\end{array}$ \\
\hline $\begin{array}{l}\mathrm{Ak} \\
\mathrm{S} \\
\mathrm{R} \\
\end{array}$ & $\begin{array}{l}35 \\
7 \\
\end{array}$ & $\begin{array}{l}14 \\
2 \\
\end{array}$ & $\begin{array}{l}12 \\
2 \\
\end{array}$ & $\begin{array}{l}7 \\
6 \\
\end{array}$ & $\begin{array}{l}10 \\
3 \\
\end{array}$ & $\begin{array}{l}1 \\
1 \\
\end{array}$ & $\begin{array}{l}4 \\
1 \\
\end{array}$ & $\begin{array}{l}3 \\
2 \\
\end{array}$ \\
\hline $\begin{array}{l}\mathrm{Gm} \\
\mathrm{S} \\
\mathrm{R} \\
\end{array}$ & $\begin{array}{l}34 \\
8 \\
\end{array}$ & $\begin{array}{l}14 \\
2 \\
\end{array}$ & $\begin{array}{l}10 \\
4 \\
\end{array}$ & $\begin{array}{l}4 \\
7 \\
\end{array}$ & $\begin{array}{l}10 \\
3 \\
\end{array}$ & $\begin{array}{l}1 \\
1 \\
\end{array}$ & $\begin{array}{l}3 \\
2 \\
\end{array}$ & $\begin{array}{l}2 \\
3 \\
\end{array}$ \\
\hline $\begin{array}{l}\mathrm{Ctx} \\
\mathrm{S} \\
\mathrm{R} \\
\end{array}$ & $\begin{array}{l}6 \\
36 \\
\end{array}$ & $\begin{array}{l}11 \\
5 \\
\end{array}$ & $\begin{array}{l}8 \\
6 \\
\end{array}$ & $\begin{array}{l}2 \\
11 \\
\end{array}$ & $\begin{array}{l}9 \\
4 \\
\end{array}$ & $\begin{array}{l}1 \\
1 \\
\end{array}$ & $\begin{array}{l}0 \\
5 \\
\end{array}$ & $\begin{array}{l}0 \\
5 \\
\end{array}$ \\
\hline $\begin{array}{l}\text { Nit } \\
\mathrm{S} \\
\mathrm{R} \\
\end{array}$ & $\begin{array}{l}34 \\
8 \\
\end{array}$ & $\begin{array}{l}14 \\
2 \\
\end{array}$ & $\begin{array}{l}13 \\
1 \\
\end{array}$ & $\begin{array}{l}8 \\
5 \\
\end{array}$ & $\begin{array}{l}8 \\
5 \\
\end{array}$ & $\begin{array}{l}1 \\
1 \\
\end{array}$ & $\begin{array}{l}4 \\
1 \\
\end{array}$ & $\begin{array}{l}4 \\
1 \\
\end{array}$ \\
\hline $\begin{array}{l}\text { Imp } \\
\mathrm{S} \\
\mathrm{R} \\
\end{array}$ & $\begin{array}{l}40 \\
2 \\
\end{array}$ & - & - & $\begin{array}{l}10 \\
3 \\
\end{array}$ & - & $\begin{array}{l}2 \\
0 \\
\end{array}$ & $\begin{array}{l}5 \\
0 \\
\end{array}$ & $\begin{array}{l}4 \\
1 \\
\end{array}$ \\
\hline $\begin{array}{l}\text { Cip } \\
\text { S } \\
\mathrm{R} \\
\end{array}$ & $\begin{array}{l}4 \\
38 \\
\end{array}$ & $\begin{array}{l}11 \\
5 \\
\end{array}$ & $\begin{array}{l}5 \\
9 \\
\end{array}$ & $\begin{array}{l}0 \\
13 \\
\end{array}$ & $\begin{array}{l}1 \\
12 \\
\end{array}$ & $\begin{array}{l}0 \\
2 \\
\end{array}$ & $\begin{array}{l}1 \\
4 \\
\end{array}$ & $\begin{array}{l}0 \\
5 \\
\end{array}$ \\
\hline $\begin{array}{l}\text { le } \\
\mathrm{S} \\
\mathrm{R} \\
\end{array}$ & $\begin{array}{l}5 \\
37 \\
\end{array}$ & $\begin{array}{l}11 \\
5 \\
\end{array}$ & $\begin{array}{l}6 \\
8 \\
\end{array}$ & $\begin{array}{l}1 \\
12 \\
\end{array}$ & $\begin{array}{l}1 \\
12 \\
\end{array}$ & $\begin{array}{l}0 \\
2 \\
\end{array}$ & $\begin{array}{l}2 \\
3 \\
\end{array}$ & $\begin{array}{l}0 \\
5 \\
\end{array}$ \\
\hline $\begin{array}{l}\text { Pit } \\
\text { S } \\
\mathrm{R} \\
\end{array}$ & $\begin{array}{l}5 \\
37 \\
\end{array}$ & $\begin{array}{l}12 \\
4 \\
\end{array}$ & $\begin{array}{l}6 \\
8 \\
\end{array}$ & $\begin{array}{l}6 \\
7 \\
\end{array}$ & $\begin{array}{l}7 \\
6 \\
\end{array}$ & $\begin{array}{l}1 \\
1 \\
\end{array}$ & $\begin{array}{l}2 \\
3 \\
\end{array}$ & $\begin{array}{l}1 \\
4 \\
\end{array}$ \\
\hline $\begin{array}{l}\text { Cfs } \\
\text { S } \\
\mathrm{R} \\
\end{array}$ & $\begin{array}{l}20 \\
22 \\
\end{array}$ & $\begin{array}{l}12 \\
4\end{array}$ & $\begin{array}{l}7 \\
7 \\
\end{array}$ & $\begin{array}{l}7 \\
6 \\
\end{array}$ & $\begin{array}{l}13 \\
0 \\
\end{array}$ & $\begin{array}{l}2 \\
0 \\
\end{array}$ & $\begin{array}{l}4 \\
1 \\
\end{array}$ & $\begin{array}{l}1 \\
4 \\
\end{array}$ \\
\hline
\end{tabular}

Table 3: Prevalence of NFT resistance among the bacterial isolates- $(n=111)$

\begin{tabular}{|l|l|l|l|}
\hline Organism & Number & NFT sensitive $(\%)$ & NFT resistant $(\%)$ \\
\hline E. coli & 42 & $34(80.95)$ & $8(19.04)$ \\
\hline CONS & 16 & $14(87.5)$ & $2(12.5)$ \\
\hline S. aureus & 14 & $13(92.85)$ & $1(7.1)$ \\
\hline Klebsiella sp. & 13 & $8(61.54)$ & $5(38.46)$ \\
\hline Enterococcus Sp. & 13 & $8(61.54)$ & $5(38.46)$ \\
\hline Proteus sp. & 2 & $1(50)$ & $1(50)$ \\
\hline Citrobactor sp. & 5 & $4(80)$ & $1(20)$ \\
\hline Pseudomonas sp. & 5 & $4(80)$ & $1(20)$ \\
\hline Serratia sp. & 1 & $1(100)$ & 0 \\
\hline
\end{tabular}




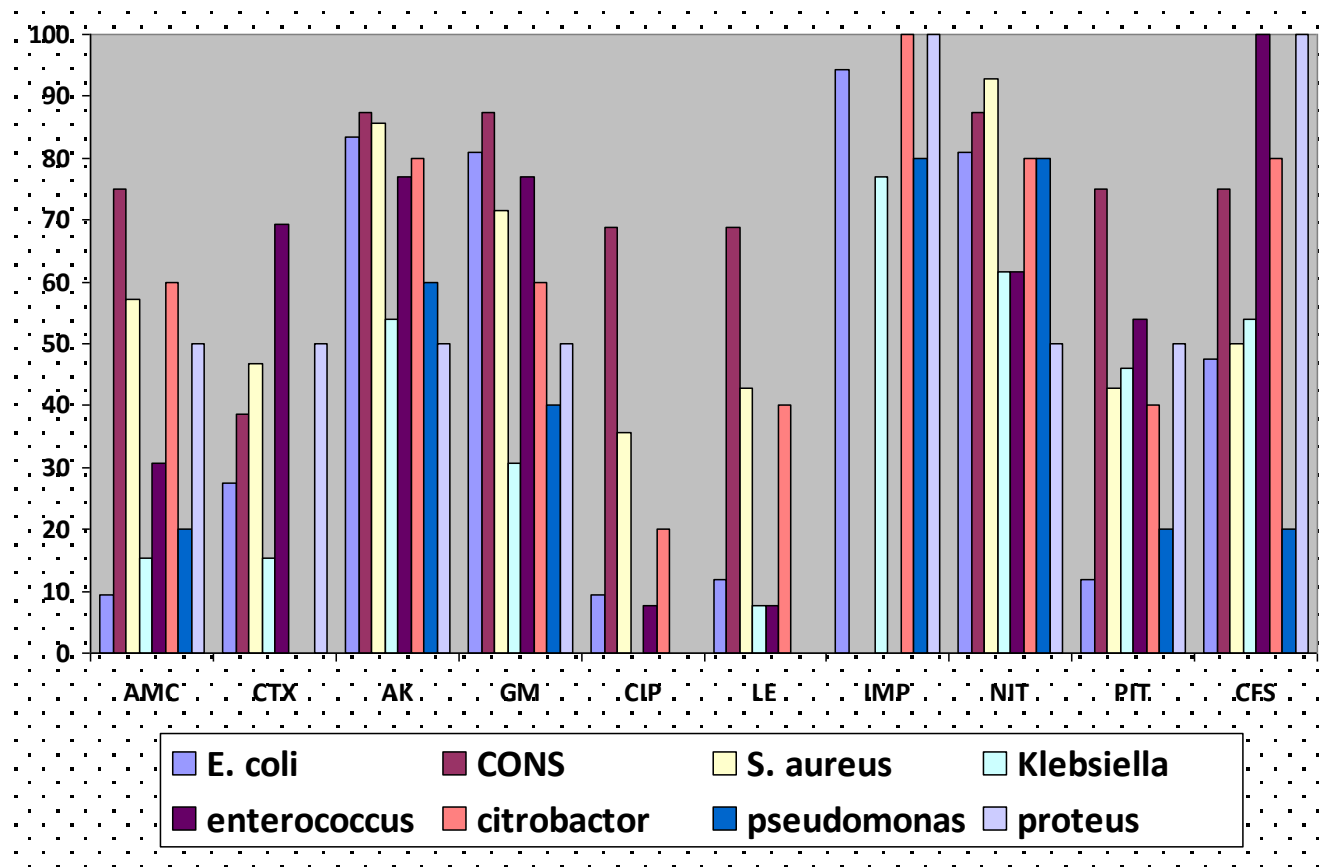

Figure 1: sensitivity pattern (in percentage) of common urinary isolates against commonly used antibiotics

\section{Discussion}

Urinary tract infections (UTI) are common infections in both community and hospital set up. Treatment of UTI varies with the type of involvement -upper or lower UTI, type of organism, as well as age, sex and underlying disease of the patient. ${ }^{2}$ The aetiology of UTIs is predictable with Escherichia coli being the principal pathogen. ${ }^{3}$ other common isolates were Klebsiella species, coagulase negative Staphylococcus, Staphylococcus aureus, Enterococcus species. The rate of isolation of other gram negative uropathogens was relatively less in our study in comparison to the 'urinary tract infection study group' in Turkey lead by Arslan et al in $2004 .{ }^{4}$ The most commonly used antibacterial drugs in the treatment of community-acquired UTIs are Trimethoprim/sulfamethoxazole, ciprofloxacin, cephalosporins, semi-synthetic penicillins with or without inhibitors, nitrofurantoin and fosfomycin. ${ }^{6}$ In treatment of UTIs, trimethoprim/ sulfamethoxazole is the recommended drug in settings where the prevalence of resistance is $<10-20 \%$ according to the Infectious Diseases Society of America (IDSA) guidelines. ${ }^{2}$ Fluoroquinolones are the drugs of choice if the trimethoprim/sulfamethoxazole resistance rate is higher than $20 \% .^{2}$ Fluoroquinolones are potent antimicrobials, have been in clinical use for the last two decades, ${ }^{6}$ and have been more commonly prescribed for communityacquired UTIs, although there is evidences of increasing fluoroquinolones resistance worldwide. An association between the increase in quinolone prescriptions and an increase in bacterial resistance has been reported from several different countries. ${ }^{6-9}$

In this study, fluoroquinolone resistance of E. coli was found to be more than $80 \%$. A high level of resistance was observed for beta-lactam antibiotics, and beta lactam-beta lactamase inhibitors combination drugs. But in vitro susceptibility to nitrofurantion was quite high $(80.95 \%)$. This report goes in harmony with the report of Giancarlo Schito, MD, (Italy), who presented an epidemiological and surveillance study involving 9 countries. Their study found that for E.coli isolates susceptibility was highest for fosfomycin (98.4\%), followed by mecillinam (95.9\%), nitrofurantoin (95.2\%), ciprofloxacin (91.2\%), amoxicillin/clavulanic acid $(82.6 \%)$, cefuroxime $(80.9 \%)$, cotrimoxazole $(71.1 \%)$, and lowest for ampicillin (45.0\%). Fosfomycin, mecillinam, and nitrofurantoin have preserved their overall in vitro efficacy. ${ }^{10}$ According to these patterns of E. coli prevalence and resistance, ampicillin, cotrimoxazole, and cefuroxime should not be recommended for empiric therapy of UTI in all countries monitored. The increase in quinolone resistance among communityacquired urinary E. coli is a cause of concern. In a study (in 2004) by Hooton, Besser and Foxman, Nitrofurantoin was recommended for treating or preventing only uncomplicated cystitis and resistance to E. coli has been reported to be very low even after 50 years of use. ${ }^{11}$

\section{Conclusion}

Various studies showed that empirical therapy of community acquired uncomplicated UTI with fluoroquinolones or beta lactam antibiotics may be less effective due to higher rates of resistance, whereas nitrofurantion may be a reasonable alternative due to much lower rate of resistance. Though nitrofurantion 
resistance is also increasing and the data in our study is higher than some previous studies, it is still lower than the other antibiotics so it's role in treating the patients with uncomplicated UTI should be considered again.

This study has not touched the sensitive topic of complicated UTI in individuals with low Glomerular filtration Rate (GFR), which rules out nitrofurantoin, tetracycline and Sulfa compounds. Yes, this is a difficult time.

\section{References}

[1]. Urinary Tract Infections and Resistant Bacteria: Highlights of a Symposium at the Combined Meeting of the 25th International Congress of Chemotherapy (ICC) and the 17th European Congress of Clinical Microbiology and Infectious Diseases (ECCMID), March 31-April 3, 2007, Munich, Germany. Reviews in Urology 2007; VOL. 9 NO. 2:78-80

[2]. Livermore DM, Warner M, Mushtaq S, Doumith M, Zhang J, Woodford N. What remains against carbapenem-resistant Enterobacteriaceae? Evaluation of chloramphenicol, ciprofloxacin, colistin, fosfomycin, minocycline, nitrofurantoin, temocillin and tigecycline. Int J Antimicrob Agents. 2011 Mar 21.

[3]. Warren JV, Abrutyn E, Hebel R et al. Guidelines for the treatment uncomplicated acute bacterial cystitis and acute pyelonephritis in women. Clin Infect Dis 1999; 29: 745-58.

[4]. Karlowsky JA, Jones ME, Thornsberry C et al. Prevalence of antimicrobial resistance among urinary tract pathogens isolated from female outpatients across the US in 1999. Int J Antimicrob Agents 2001; 18:121-7.

[5]. Risk factors for ciprofloxacin resistance among Escherichia coli strains isolated from community-acquired urinary tract infections in Turkey Hande Arslan, Ozlem Kurt Azap, O "nder Ergo "nu“ and Funda Timurkaynak on behalf of the Urinary Tract Infection Study Group. Journal of Antimicrobial Chemotherapy (2005) 56, 914-918 doi:10.1093/jac/dki344

[6]. Hryniewicz K,SzczypaK, Sulikowska Aet al. Antibiotic susceptibility of bacterial strains isolated from urinary tract infections in Poland.J Antimicrob Chemother 2001; 47: 773-80.

[7]. Zervos MJ, Hershberger E, Nicolau DP et al. Relationship between fluoroquinolone use and changes in susceptibility to fluoroquinolones ofselected pathogens in 10 United States teaching hospitals, 1991-2000.Clin Infect Dis 2003; 37: 1643-8

[8]. Goettsch W, Pelt W, Nagelkerke N et al. Increasing resistance to fluoroquinolones in Escherichia coli from urinary tract infections in The Netherlands. J Antimicrob Chemother 2000; 46: 223-8.

[9]. Karlowsky JA, Kelly LJ, Thornsberry C et al. Trends in antimicrobial resistance among urinary tract infection isolates of Escherichia coli from female outpatients in the United States. Antimicrob Agents Chemother 2002; 46: 2540-5.

[10]. Ena J, Amador C, Martinez C et al. Risk factors for acquisition of urinary tract infections caused by ciprofloxacin-resistant Escherichia coli. J Urol 1995; 153: 117-20.

[11]. Schito G. Epidemiology and resistance in uncomplicated UTI-a recent European study (ARESC). Presented at: Combined Meeting of the 25th International Congress of Chemotherapy and the 17th European Congress of Clinical Microbiology and Infectious Diseases; March 31-April 3, 2007; Munich, Germany.

[12]. HootonTM, Besser R, FoxmanBet al. (2004). Acute uncomplicatedcystitis in an era of increasing antibiotic resistance: a proposed approachto empirical therapy. Clin Infect Dis 2004; 39: 75-80.

[13]. Alos JI, Serrano MG, Gomez-Garces JL et al. Antibiotic resistance of Escherichia coli from community-acquired urinary tract infections in relation to demographic and clinical data. Clin Microbiol Infect 2005;11: 199-203.

[14]. Kahlmeter G. An international survey of the antimicrobial susceptibility of pathogens from uncomplicated urinary tract infections: the ECO·SENS Project. J Antimicrob Chemother 2003; 51: 69-76

[15]. Hooton TM. Fluoroquinolones and resistance in the treatment of uncomplicated urinary tract infection. Int $\mathbf{J}$ Antimicrob Agents 2003; 22:S65-S72. 